\title{
Telomerase Activity in Cell Lines of Pediatric Soft Tissue Sarcomas
}

\author{
ELKE KLEIDEITER, MATTHIAS SCHWAB, ULRIKE FRIEDRICH, EWA KOSCIELNIAK, \\ BEAT W. SCHÄFER, AND ULRICH KLOTZ
}

\begin{abstract}
Dr. Margarete Fischer-Bosch Institute of Clinical Pharmacology, D-70376 Stuttgart, Germany [E.K., M.S., U.F., U.K.J, Department of Pediatric Oncology/Hematology, Olga Hospital, D-70176 Stuttgart, Germany [E.K.], and Division of Clinical Chemistry and Biochemistry, Department of Pediatrics, University Hospital, CH-8032 Zürich, Switzerland [B.W.S.]
\end{abstract}

\begin{abstract}
Telomeres and their maintenance by telomerase have been implicated to play an important role in carcinogenesis. As almost all malignant tumors express telomerase (in contrast to normal somatic cells), assessment of its activity has been proposed as a diagnostic and prognostic tool. To test the prognostic value of telomerase in pediatric soft tissue sarcoma (STS), we analyzed telomere length (by telomere restriction fragment analysis), telomerase activity (by modified telomerase repeat amplification protocol assay), and expression of human telomerase reverse transcriptase (hTERT) mRNA (by TaqMan technique) in cell lines of different types of STS from 12 children and adolescents. Telomere length $(3.7-9.0 \mathrm{~kb})$ showed a very heterogeneous pattern, independent of subtype of STS or the age of the patients, and it was not associated with expression of hTERT mRNA. In contrast, there was a trend of an association between hTERT and telomerase activity. The three tested cell lines of embryonal rhabdomyosarcomas demonstrated no or low $(n=2)$ telomerase activity, which was confirmed in two cases by a very low
\end{abstract}

\section{ABSTRACT}

expression of hTERT mRNA. Thus, we suggest that the significant difference $(p<0.01)$ in the less aggressive clinical behavior of embryonal rhabdomyosarcomas in comparison to other subtypes may be due to differences in telomerase expression. Taken together, our cell line experiments imply that telomerase activity might be a biologic marker for stratification between STS with different clinical prognosis. (Pediatr Res 54: 718-723, 2003)

Abbreviations
TRF, telomere restriction fragment
TRAP, telomerase repeat amplification protocol
STS, soft tissue sarcoma
hTERT, human telomerase reverse transcriptase
RME, embryonal rhabdomyosarcoma
RMA, alveolar rhabdomyosarcoma
PNET, peripheral neuroectodermal tumor
RT, rhabdoid tumor

There is now increasing evidence that maintenance of telomeres plays an important role during cellular aging and carcinogenesis $(1,2)$. Telomeres represent the end of chromosomes and consist of repetitive nucleotide units with the sequence $(\text { TTAGGG })_{n}$. They serve to protect linear chromosomes from damage and provide the structural basis for solving the socalled "end replication problem" $(3,4)$. With each cell division, telomeres show a progressive loss of their length, and at a critical limit normally cells stop dividing and enter senescence $(1,4)$. Such critical shortening can be prevented by the

Received September 4, 2002; accepted May 28, 2003.

Correspondence: U. Klotz, Ph.D., Dr. Margarete Fischer-Bosch Institute of Clinical Pharmacology, Auerbachstr. 112, D-70376 Stuttgart, Germany; e-mail: ulrich.klotz@ ikp-stuttgart.de

Supported by the Robert Bosch Foundation Stuttgart, Germany, and by Krebsforschung Schweiz (to B.W.S.).

Current address: Ulrike Friedrich, Pharmacy Department of the Hospital, D-78056 Villingen-Schwenningen, Germany.

DOI: 10.1203/01.PDR.0000086901.29111.2A multisubunit enzyme telomerase comprised of a RNA template component (hTR), the catalytic reverse transcriptase component (hTERT), and regulatory proteins (5). The ribonucleoprotein telomerase adds additional TTAGGG repeats at the ends of telomeres and its activity is down-regulated in most postembryonic cell types (6). However, in most cancer cells telomerase expression is activated, and this can lead to cellular immortalization. Thus, acquisition of telomerase activity is a crucial step in restoring the replicative potential of cells and in initiating human cell transformation (7).

Therefore, telomerase has been a focus in cancer research, especially in evaluating its role in carcinogenesis, in determining its diagnostic and prognostic value in different types of human cancer, and in testing its potential as a target for anticancer chemotherapy $(8,9)$. As telomerase activity has been detected in $85-95 \%$ of various human cancers $(2,10)$ and because of its superior sensitivity and clinical specificity compared with other conventional diagnostic methods (11), its value as a sensitive tumor marker is increasingly accepted. In 
addition, assessment of the hTERT mRNA has been performed to test whether its expression is related to telomerase activity. In that case, hTERT mRNA measurements could be used as a kind of surrogate to provide useful information on telomerase. However, it must be demonstrated that a strong correlation exists between telomerase activity and hTERT (12-14).

STS represent a heterogeneous group of malignant mesenchymal tumors. In adults, controversial results have been reported regarding whether telomerase plays an important role in their tumorigenesis. In two studies, the presence of telomerase activity appeared to be indicative of malignancy and survival $(15,16)$, however, in two other studies, it was suggested that telomerase did not play an important role in STS and that it is not a reliable marker of tumor malignancy/aggressiveness (14, 17). Moreover, no detailed data have been reported so far on pediatric STS, where great difficulties exist in regard to diagnosis and treatment strategies (18). RME, RMA, and PNET are among the most frequently diagnosed subtypes of pediatric STS, and, according to clinical data, RME has the most favorable prognosis (19-21). However, it remains to be elucidated what the underlying mechanisms are for the better outcome of RME if compared with other subtypes, especially RT.

To investigate whether telomere length and telomerase activity (or hTERT) are associated with the clinical prognosis of pediatric STS, we assessed these biochemical markers in cell lines derived from different types of STS. Any relationship between biochemical data and prognostic information on the different STS types could provide helpful links for better diagnostic and therapeutic strategies.

\section{MATERIAL AND METHODS}

Patients. Tumor material was obtained from 12 pediatric patients with STS (median age, 2.6 y; six females). Diagnosis and subtype of STS was based on histology by reference pathologists and confirmed by additional molecular analysis, which is specific for STS (Table 1) (22-24). Most of the patients were participants in the German Cooperative STS Study CWS (18). The study was approved by the local ethics committee, and informed consent was obtained from the parents.

Cells and cell cultures. The biologic specimens (taken from primary tumors and metastasis) were used to establish cell cultures. The isolated cells were grown in Roswell Park Memorial Institute (RPMI) 1640 medium (Biochrom, Berlin, Germany) supplemented with $10 \%$ FCS (Biochrom), $100 \mathrm{U} / \mathrm{mL}$ penicillin, and $100 \mu \mathrm{g} / \mathrm{mL}$ streptomycin (Biochrom) in $5 \%$ $\mathrm{CO}_{2}$ at $37^{\circ} \mathrm{C}$. Three of the cell lines used have been described previously $(20,22,25)$. All cell lines were grown under the same culture conditions.

Determination of telomere length. Average telomere length was determined in duplicate whenever sufficient DNA was available by a standard procedure as outlined recently $(26,27)$. To consider possible telomere repeat variations in STS, we estimated the telomere length of EDTA-treated whole blood samples of seven age- and gender-matched children without STS (controls). The 1 kb-DNA ladder (Invitrogen, Karlsruhe,
Germany) and the digoxigenin-labeled DNA molecular weight marker II (Roche Molecular Biochemicals, Mannheim, Germany) served as base pair markers. TRF were obtained from genomic DNA by digestion with the restriction enzyme HinfI (New England Biolabs, Schwalbach, Germany). Integrity of the DNA and successful digestion was monitored before and after digestion by agarose gel electrophoresis. After resolving the TRF by electrophoresis on a $0.8 \%$ agarose gel, the DNA fragments were transferred onto a nylon membrane (Roche Molecular Biochemicals) with $20 \times$ SSC (standard saline citrate) buffer and cross-linked by UV irradiation. The Southern blot was hybridized with a digoxigenin-labeled (TTAGGG) $)_{7}$ telomeric probe (Roth, Karlsruhe, Germany), and the TRF were detected by chemiluminescence following the manufacturer's instructions (Roche Molecular Biochemicals). The filters were exposed within the linear range of the chemiluminescence reaction and the films (Hyperfilm, Amersham Buchler, Braunschweig, Germany) were scanned and analyzed using the One-Dscan 1.0 (Scanalytics, Inc., Fairfax, VA, U.S.A.) and Excel 97 software (Microsoft Corporation, Redmond, WA, U.S.A.).The mean TRF length was calculated as weighted mean of the $\mathrm{OD}$ using the formula $\mathrm{L}=\Sigma\left(\mathrm{OD}_{\mathrm{i}}\right.$. $\left.\mathrm{L}_{\mathrm{i}}\right) / \Sigma O \mathrm{D}_{\mathrm{i}}$, with $\mathrm{OD}_{\mathrm{i}}$ as the integrated signal in interval $\mathrm{i}$ and $\mathrm{L}_{\mathrm{i}}$ as the TRF length at the midpoint of interval i.

Telomerase activity assay. Telomerase activity in cells was detected by the modified TRAP assay using the TRAPeze telomerase detection kit (Q-BIOgene, Heidelberg, Germany), which is based on the method described by Kim et al. (10). The assay is a one-buffer, two-enzyme system using the PCR. In the first step of the assay, telomerase adds the 6-bp telomeric sequence (TTAGGG) onto the $3^{\prime}$ end of a $5^{\prime}$ end infrared dye-labeled oligonucleotide substrate (5'-AATCCGTCGAGCAGAGTT-3') (TS Primer, MWG Biotech, Ebersberg, Germany). In the second step, the extended products are amplified by PCR. Briefly, $10^{6}$ cells of each sample were resuspended in $200 \mu \mathrm{L}$ of 3-[(3-cholamidopropyl)dimethyl-ammonio]-1propanesulfonate (CHAPS) lysis buffer (TRAPeze) and incubated for $30 \mathrm{~min}$ on ice. After the incubation, lysates were centrifuged at $12,000 \times g$ for $20 \mathrm{~min}$ at $4^{\circ} \mathrm{C}$. The supernatant was recovered, and the protein concentration was measured using the Biciuchoriuic acid (BCA) test. Aliquots of different protein concentrations were tested by the TRAP assay. Because the best differentiation of the samples was seen with extracts containing $0.05 \mu \mathrm{g}$ protein, we used this concentration as the standard concentration. To check for the presence of PCR inhibitors, the extracts containing $0.05 \mu \mathrm{g}$ protein were diluted 10-fold and reanalyzed. Sample extracts were mixed with A549 (DSMZ, Braunschweig, Germany) telomerasepositive cell extracts to exclude false-negative results. TSR8 and CHAPS buffer (TRAPeze) were used as positive and negative controls, respectively. After a 30-min incubation at $30^{\circ} \mathrm{C}$, the samples were subjected to $33 \mathrm{PCR}$ cycles of $94^{\circ} \mathrm{C}$ for $30 \mathrm{~s}$ and $57^{\circ} \mathrm{C}$ for $30 \mathrm{~s}$ (PTB Thermal Cycler, Lab-Line, CLF, Emersacker, Germany). The PCR products were separated by electrophoresis on nondenaturing polyacrylamide gels. The typical 6-bp DNA incremental ladder of telomerase products 


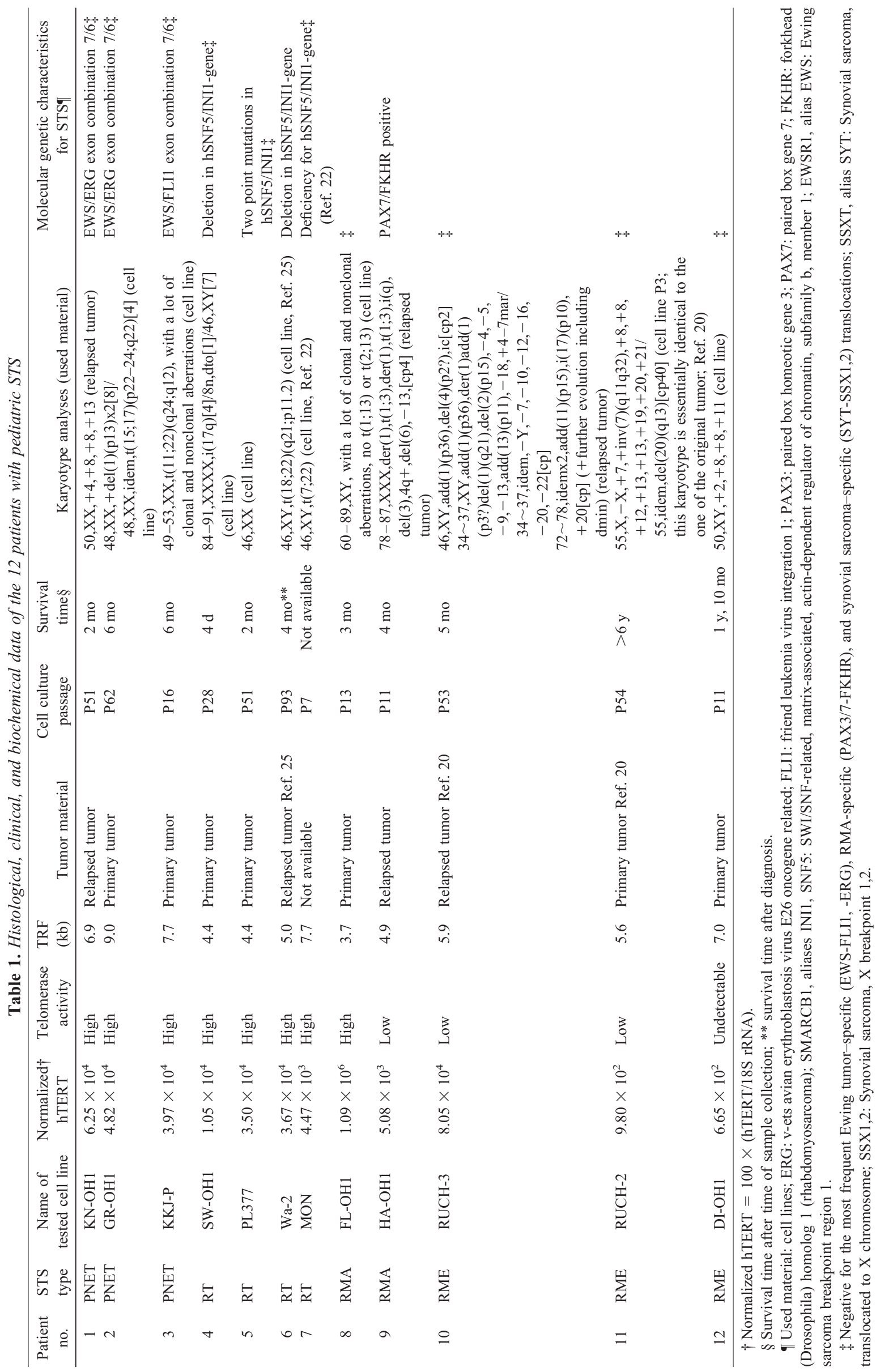


was detected by an infrared laser of a DNA sequencer (MWG Biotech). A sample was scored as telomerase positive when the specific 6-bp DNA ladder was observed. Telomerase activity was characterized by a semiquantitative score $(0=$ undetectable, $1=$ low, $2=$ high) that was based on the comparison of the telomerase ladder (number and intensity of the bands) of the investigated samples.

Expression of hTERT by reverse-transcriptase PCR. Total RNA was collected from samples by using RNeasy Mini Kit (Qiagen, Hilden, Germany), which included a DNase I treatment of the samples with the RNase-Free DNase Set (Qiagen, Hilden, Germany). The quality of the RNA samples was determined by electrophoresis through formaldehyde-agarose gels and staining with ethidium bromide, and the $18 \mathrm{~S}$ and $28 \mathrm{~S}$ rRNA bands were visualized under UV light. cDNA was synthesized from $2 \mu \mathrm{g}$ of total RNA using the TaqMan Reverse Transcription Reagents kit (Applied Biosystems, Foster City, CA, U.S.A.) according to the instructions of the manufacturer. After random hexamers annealed for $10 \mathrm{~min}$ at $25^{\circ} \mathrm{C}$, cDNA synthesis was performed for $60 \mathrm{~min}$ at $48^{\circ} \mathrm{C}$, followed by an inactivation step for $5 \mathrm{~min}$ at $95^{\circ} \mathrm{C}$. For PCR analysis, the cDNA samples were amplified in a $25-\mu \mathrm{L}$ reaction mixture containing $1 \times$ TaqMan Universal Master Mix (Applied Biosystems), $300 \mathrm{nM}$ of the primers, and $150 \mathrm{nM}$ of the TaqMan probe. We have used the identical primer and probe sequences as described by Bièche et al. (28) for amplification of hTERT. The hTERT expression was normalized to the amount of RNA input using 18S rRNA expression, which also served as an endogenous control. 18S rRNA primers and probes were taken from the TaqMan Ribosomal RNA Control Reagents kit (Applied Biosystems). The standard curves for hTERT and 18S rRNA were prepared using the A549 lung carcinoma cell line, which highly expresses telomerase activity. The cDNA was obtained by reverse transcription and diluted to produce standard curves covering a concentration range of $0.001-200 \mathrm{ng}$. PCR programming was $2 \mathrm{~min}$ at $50^{\circ} \mathrm{C}$ and $10 \mathrm{~min}$ at $95^{\circ} \mathrm{C}$ for enzyme activation, followed by 40 two-step cycles $(15 \mathrm{~s}$ at $95^{\circ} \mathrm{C} ; 1 \mathrm{~min}$ at $60^{\circ} \mathrm{C}$ ). Samples were measured in triplicate. All PCR reactions were performed using an ABI Prism 7700 Sequence Detection System (Applied Biosystems) and transformed to nanograms of A549 hTERT and A549 18S rRNA using the standard curves. The ratio between nanograms of hTERT and nanograms $18 \mathrm{~S}$ rRNA represents the normalized hTERT $\left(\right.$ hTERT $\left._{\mathrm{N}}\right)$ value of each sample.

Alkaline phosphatase activity. Assays of alkaline phosphatase activity served as an internal control for the quality of each extract (29).

Statistical analysis. Statistical tests were performed using the GraphPad Prism 3.0 software (GraphPad Software, San Diego, CA, U.S.A.). Telomerase activity scores between STS with favorable (RME) and unfavorable prognosis [all other types including RMA or excluding RMA $(21,30)]$ were compared using the Kruskal-Wallis test with subsequent Dunn's multiple comparison test. To compare two groups (TRF values between controls and STS) we used the Mann-Whitney test. Values of $p<0.05$ were considered statistically significant.

\section{RESULTS}

Estimation of telomere length. The described TRF Southern blot analysis was applied, and representative examples are illustrated in Figure 1. Independent of the subtype of STS or the age of the patients, a wide interindividual variability (3.7$9.0 \mathrm{~kb}$ ) in telomere length could be observed (Table 1). In PNET, TRF was somewhat (NS) longer (mean, $7.9 \mathrm{~kb}$ ) than in RME (mean, $6.2 \mathrm{~kb}$ ), RT (mean, $5.4 \mathrm{~kb}$ ), and RMA, which had the shortest TRF (mean, $4.3 \mathrm{~kb}$ ). The TRF of the seven control samples averaged $8.5 \pm 0.5 \mathrm{~kb}$ (mean $\pm \mathrm{SD}$ ) and was significantly longer $(p<0.005)$ than that of the STS patients $(6.0 \pm$ $1.6 \mathrm{~kb})$.

Determination of telomerase activity. Based on the conditions applied (see "Materials and Methods"), telomerase activity could be classified either as undetectable, low (borderline), or high. The interindividual assessments are summarized in Table 1. Four of the 12 tested cell lines demonstrated no or low telomerase activity (Fig. 2) at $0.05 \mu$ g protein and no activity $(n=3)$ at the 10-fold dilution of the extracts. When the negative RME sample was mixed with A549 cells, no decrease in the activity of the telomerase-positive cell extracts was observed. One sample with borderline telomerase activity was derived from a relapsed RME tumor sample. In contrast, in other subtypes (PNET, RT) of STS high telomerase activity was present. One of two cases with RMA also demonstrated a low activity. Thus, in terms of a favorable prognosis, telomerase activity was significantly $(p<0.01)$ different between RME and all other subtypes of STS. When we compared RME

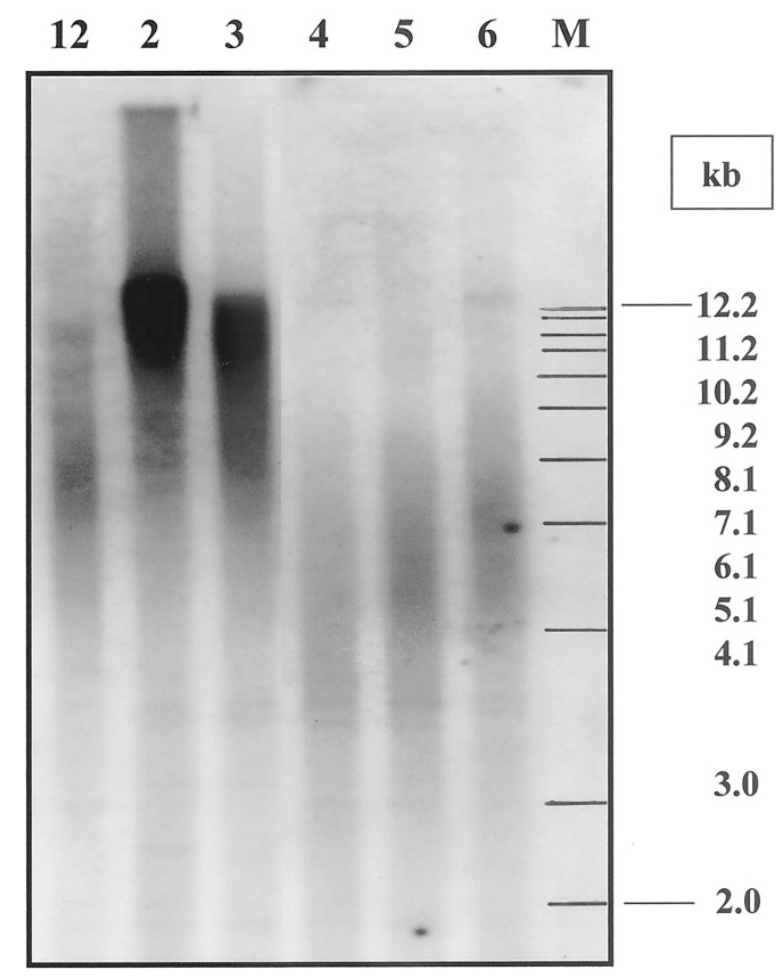

Figure 1. Representative examples of Southern blot analyses of TRF in cell lines generated from tumor samples of patients with pediatric STS (patient number is given on top). $M$ shows the molecular weight marker (1-kb ladder) with the sizes indicated in the right margin. 


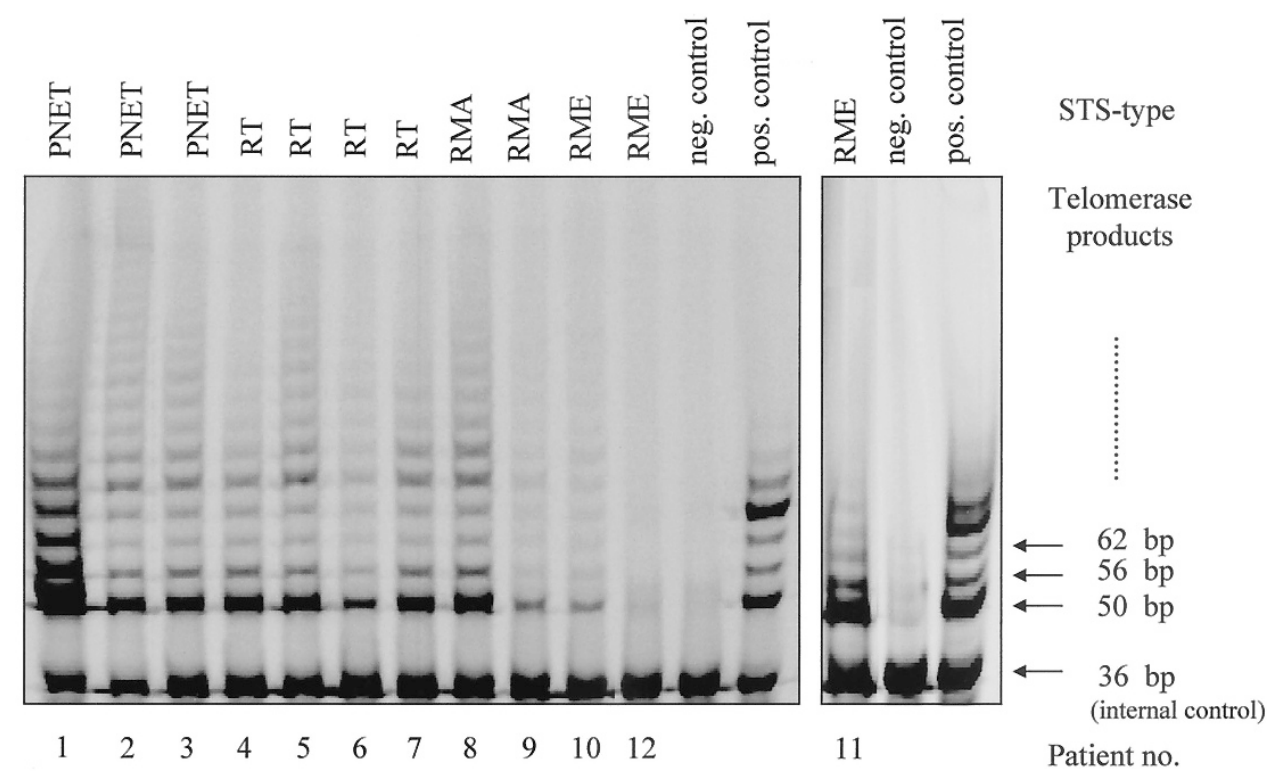

Figure 2. TRAP gel assay of the tumor samples. The modified TRAP assay was used to analyze the telomerase activity of the tumor samples. The gel demonstrates the telomerase activity of different STS cell lines under standard condition at $0.05 \mu \mathrm{g}$ protein. The three patients with RME showed low or no telomerase activity (patients $10-12$ ), whereas patients $1-8$ had high telomerase activity.

with other subtypes of STS excluding RMA, the difference remained statistically significant $(p<0.01)$.

Expression of hTERT mRNA. The individual normalized hTERT values are given in Table 1. HTERT expression of all samples showed a high variability and ranged from $6.65 \times 10^{2}$ to $1.09 \times 10^{6}$. Although a statistically significant association between hTERT expression and telomerase activity was not found, a trend of an association between both measures was observed. Two cases with undetectable and low telomerase activity showed a very low expression of hTERT. In contrast the highest hTERT expression was found in one case with low telomerase activity (patient 8, RMA).

\section{DISCUSSION}

STS represent a group of very heterogeneous tumors with different histologic subtypes that are quite common in childhood and adolescence (18-21). As telomerase appears to be involved in carcinogenesis, this ribonucleoprotein has gained great attention in cancer research, especially as it might serve not only as a diagnostic but also as a prognostic marker (1-4, 7-10). However, it must be emphasized that for STS in adults, the claimed prognostic potential of telomerase $(15,16)$ was not confirmed by others $(14,17)$.

Likewise, telomere shortening leading to genetic instability is discussed as an important mechanism in tumorigenesis, and reduction in telomere length has been detected in many cancer cells, including liposarcomas $(31,32)$. These observations are consistent with our findings that the investigated STS had significantly $(p<0.005)$ shorter telomeres than the control samples. In general, a quite large variability in TRF has been observed, which might be due to type and grading of the heterogeneous tumors, the activity of telomerase, or the presence of alternative mechanisms of TRF maintenance (33-35). Our results on TRF confirm the observed wide interindividual variability and suggest that this parameter cannot be used as diagnostic and prognostic marker for STS. However, larger number of tumors should be investigated to allow general conclusions.

With respect to telomerase, it might be anticipated that insufficient activity might result in critically shortened telomeres leading to a subsequent stop of cellular proliferation. This mechanism could have been in effect in our patients 11 and 12 (Table 1) because the cell lines showed undetectable or low telomerase activity and the course of prognosis in these both patients was more favorable (RME).

With the exception of one case, there was an association of telomerase activity and expression of hTERT mRNA similar to a study in adult patients with STS (14). In general, our results in children and those of Yan et al. in adults $(14,35)$ indicate a heterogeneous pattern of hTERT expression that does not correlate in each case with telomerase activity. Discrepancies between both parameters, such as in one of our patients with low telomerase activity (not due to telomerase/PCR inhibitors as tested always by serial dilutions) but high expression of hTERT, might indicate the presence of spliced hTERT variants (36), abnormalities in the RNA template, or post-transcriptional modifications of the different telomerase subunits (35), which have been reported recently. Such occasional discordance between telomerase activity and hTERT mRNA has been also observed in several other types of tumors (37). Therefore, it appears prudent to use direct activity measurements to determine unequivocally the presence of telomerase.

Surprisingly, cases demonstrating no or low telomerase activity were diagnosed as RME. As this subtype of STS has a better prognosis if compared with PNET, RT, or RMA (1921), our data could imply that this clinical observation might be due to absence of telomerase activity. Likewise, it was recently postulated that low levels of telomerase activity may be pre- 
dictive of the prognosis of osteosarcoma (38). Although statistically significant findings have emerged from our experiments, limitations to interpretation of the results are recognized. First, the observed differences are based on a small sample size. Second, data were generated from cell lines and not directly from tumor tissues, which might limit clinical prediction. However, most cell lines used in our study were established from tumor material and were not experimentally immortalized. In general, based on results of previous studies it cannot be assumed that all immortal cell lines have reactivated telomerase $(33,39,40)$. We are unaware of investigations that have analyzed simultaneously telomerase activity in human tumor tissues and corresponding cell lines. However, it has been shown that absence of telomerase activity was evident in tissues of osteosarcomas and osteosarcoma-derived cell lines. This indicates that cell lines represent suitable systems to imitate the biologic behavior of tumor cells in vivo (39).

\section{CONCLUSION}

In summary, when we consider literature and our present data, the following conclusions can be drawn: Absence of telomerase activity in cell lines of STS was significantly associated with the RME subtype, which is prognostically favorable according to clinical experiences of STS studies in childhood. Thus, telomerase activity might be proposed as a biologic marker for differentiation between STS with favorable and unfavorable prognosis. Our data are the first systematic investigations of telomerase activity, telomere length, and hTERT expression in cell lines derived from pediatric STS. However, further studies are needed to elucidate the clinical impact of our results.

Acknowledgments. The authors thank Mrs. D. Weller and Mrs. K. Simon-Klingenstein for the valuable technical assistance. The cell line MON was kindly provided by Dr. O. Delattre (Paris). We also thank Mrs. Bonilla Torres for secretarial help.

\section{REFERENCES}

1. Campisi J, Kim SH, Lim CS, Rubio M 2001 Cellular senescence, cancer and aging: the telomere connection. Exp Gerontol 36:1619-1637

2. Dhaene K, Van Marck E, Parwaresch R 2000 Telomeres, telomerase and cancer: an up-date. Virchows Arch 437:1-16

3. Blackburn EH 1991 Structure and function of telomeres. Nature 350:569-573

4. Wright WE, Shay JW 2000 Telomere dynamics in cancer progression and prevention: fundamental differences in human and mouse telomere biology. Nat Med 6:849-851

5. Wenz C, Enenkel B, Amacker M, Kelleher C, Damm K, Lingner J 2001 Human telomerase contains two cooperating telomerase RNA molecules. EMBO J 20:35263534

6. Morin GB 1989 The human telomere terminal transferase enzyme is a ribonucleoprotein that synthesizes TTAGGG repeats. Cell 59:521-529

7. Hahn WC 2001 Telomerase and cancer: where and when? Clin Cancer Res 7:29532954

8. White LK, Wright WE, Shay JW 2001 Telomerase inhibitors. Trends Biotechnol 19:114-120

9. Perry PJ, Arnold JR, Jenkins TC 2001 Telomerase inhibitors for the treatment of cancer: the current perspective. Expert Opin Investig Drugs 10:2141-2156

10. Kim NW, Piatyszek MA, Prowse KR, Harley CB, West MD, Ho PL, Coviello GM, Wright WE, Weinrich SL, Shay JW 1994 Specific association of human telomerase activity with immortal cells and cancer. Science 266:2011-2015

11. Hess JL, Highsmith Jr WE 2002 Telomerase detection in body fluids. Clin Chem $48: 18-24$
12. Nakamura TM, Morin GB, Chapman KB, Weinrich SL, Andrews WH, Lingner J, Harley CB, Cech TR 1997 Telomerase catalytic subunit homologs from fission yeast and human. Science 277:955-959

13. Hisatomi H, Nagao K, Kanamaru T, Endo H, Tonimatsu M, Hikiji K 1999 Levels of telomerase catalytic subunit mRNA as a predictor of potential malignancy. Int $\mathrm{J}$ Oncol 14:727-732

14. Yan P, Coindre JM, Benhattar J, Bosmann FT, Guillou L 1999 Telomerase activity and human telomerase reverse transcriptase mRNA expression in soft tissue tumors: correlation with grade, histology, and proliferative activity. Cancer Res 59:31663170

15. Schneider-Stock R, Rys J, Jaeger V, Niezabitowski A, Kruczak A, Sokolowski A, Roessner A 1999 Prognostic significance of telomerase activity in soft tissue sarcomas. Int J Oncol 15:775-780

16. Aogi K, Woodman A, Urquidi V, Mangham DC, Tarin D, Goodison S 2000 Telomerase activity in soft-tissue and bone sarcomas. Clin Cancer Res 6:4776-4781

17. Yoo J, Robinson RA 2000 Expression of telomerase activity and telomerase RNA in human soft tissue sarcomas. Arch Pathol Lab Med 124:393-397

18. Koscielniak E, Harms D, Henze G, Jurgens H, Gadner H, Herbst M, Klingebiel T, Schmidt BF, Morgan M, Knietig R, Treuner J 1999 Results of treatment for soft tissue sarcoma in childhood and adolescence: a final report of the German Cooperative Soft Tissue Sarcoma Study CWS-86. J Clin Oncol 17:3706-3719

19. Harms D 1995 Soft tissue sarcomas in the Kiel Pediatric Tumor Registry. In: Harms D, Schmidt D (eds) Current Topics in Pathology. Springer-Verlag, Berlin, pp 31-45

20. Scholl FA, Betts DR, Niggli FK, Schäfer BW 2000 Molecular features of a human rhabdomyosarcoma cell line with spontaneous metastatic progression. $\mathrm{Br} \mathrm{J}$ Cancer 82:1239-1245

21. Koscielniak E, Morgan M, Treuner J 2002 Soft tissue sarcoma in children: prognosis and management. Paediatr Drugs 4:21-28

22. Verstegge I, Sévenet N, Lange J, Rousseau-Merck RM, Ambros P, Handgretinger R, Aurias A, Delattre O 1998 Truncating mutations of hSNF5/INI1 in aggressive paediatric cancer. Nature 394:203-206

23. Kushner BH, LaQuaglia MP, Cheung NKV, Kramer K, Hamelin AC, Gerald WL, Ladanyi M 1999 Clinically critical impact of molecular genetic studies in pediatric solid tumors. Med Pediatr Oncol 33:530-535

24. Gordon T, McManus Aidan, Anderson J, Min T, Swansbury J, Pritchard-Jones K, Shipley J 2001 Cytogenetic abnormalities in 42 rhabdomyosarcoma: a United Kingdom Cancer Cytogenetics Group Study. Med Pediatr Oncol 36:259-267

25. Handgretinger R, Kimmig A, Koscielniak E, Schmidt D, Rudolph G, Wolburg H, Paulus W, Schilbach-Stueckle K, Ottenlinger C, Menrad A, Sproll M, Bruchelt G, Dopfer R, Treuner J, Niethammer D 1990 Establishment and characterization of a cell line (Wa-2) derived from an extrarenal rhabdoid tumor. Cancer Res 50:2177-2182

26. Friedrich U, Griese E, Schwab M, Fritz P, Thon K, Klotz U 2000 Telomere length in different tissues of elderly patients. Mech Ageing Dev 119:89-99

27. Friedrich U, Schwab M, Griese E, Fritz P, Klotz U 2001 Telomeres in neonates: new insights in fetal hematopoiesis. Pediatr Res 49:252-256

28. Bièche I, Nogues C, Paradis V, Olivi M, Bedossa P, Lidereau R, Vidaud M 2000 Quantification of hTERT gene expression in sporadic breast tumors with a real-time reverse transcription-polymerase chain reaction assay. Clin Cancer Res 6:452-459

29. Piatyszek MA, Kim NW, Weinrich SL, Hiyama K, Hiyama E, Wright WE, Shay JW 1995 Detection of telomerase activity in human cells and tumors by a telomeric repeat amplification protocol (TRAP). Methods Cell Sci 17:1-15

30. Helmke L, Engler S, Mattke A, Henne-Bruns D 2001 Extrarenal malignant rhabdoid tumors in childhood. Med Pediatr Oncol 36:317-319

31. Counter CM, Hirte HW, Bacchetti S, Harley CB 1994 Telomerase activity in human ovarian carcinoma. Proc Natl Acad Sci U S A 91:2900-2904

32. Schneider-Stock R, Epplen C, Radig K, Oda Y, Dralle H, Hoang-Vu C, Epplen JT, Roessner A 1998 On telomere shortening in soft-tissue tumors. J Cancer Res Clin Oncol 124:165-171

33. Bryan TM, Reddel RR 1997 Telomere dynamics and telomerase activity in in vitro immortalised human cells. Eur J Cancer 33:767-773

34. Hoare SF, Bryce LA, Wisman GB, Burns S, Going JJ, van der Zee AG, Keith WN 2001 Lack of telomerase RNA gene hTERC expression in alternative lengthening of telomeres cells is associated with methylation of the hTERC promoter. Cancer Res 61:27-32

35. Yan P, Benhattar J, Coindre JM, Guillou L 2002 Telomerase activity and hTERT mRNA expression can be heterogeneous and does not correlate with telomere length in soft tissue sarcomas. Int J Cancer 98:851-856

36. Ulaner GA, Hu JF, Vu TH, Giudice LC, Hoffman AR 1998 Telomerase activity in human development is regulated by human telomerase reverse transcriptase (hTERT) transcription and by alternate splicing of hTERT transcripts. Cancer Res 58:41684172

37. Kanamaru T, Tanaka KI, Kotani J, Ueno K, Yamamoto M, Idei Y, Hisatomi H, Takeyama Y 2002 Telomerase activity and hTERT mRNA in development and progression of adenoma to colorectal cancer. Int J Mol Med 10:205-210

38. Sangiorgi L, Gobbi GA, Lucarelli E, Sartorio SM, Mordenti M, Ghedini I, Maini V, Scrimieri F, Reggiani M, Bertoja AZ, Benassi MS, Picci P 2001 Presence of telomerase activity in different musculoskeletal tumor histotypes and correlation with aggressiveness. Int J Cancer 95:156-161

39. Bryan TM, Englezou A, Dalla-Pozza L, Dunham MA, Reddel R 1997 Evidence for an alternative mechanism for maintaining telomere length in human tumors and tumor-derived cell lines. Nat Med 3:1271-1274

40. Henson JD, Neumann AA, Yeager TR, Reddel R 2002 Alternative lengthening of telomeres in mammalian cells. Oncogene 21:598-610 